IZA DP No. 4780

The Role of Early-Life Conditions in the Cognitive Decline due to Adverse Events Later in Life

Gerard J. van den Berg

Dorly J.H. Deeg

Maarten Lindeboom

France Portrait

February 2010 


\title{
The Role of Early-Life Conditions in the Cognitive Decline due to Adverse Events Later in Life
}

\author{
Gerard J. van den Berg \\ University of Mannheim, VU University Amsterdam, \\ IFAU Uppsala and IZA \\ Dorly J.H. Deeg \\ VU University Amsterdam \\ Maarten Lindeboom \\ VU University Amsterdam, Tinbergen Institute, \\ HEB Bergen, Netspar and IZA \\ France Portrait \\ VU University Amsterdam and Netspar
}

Discussion Paper No. 4780

February 2010

IZA

P.O. Box 7240

53072 Bonn

Germany

Phone: +49-228-3894-0

Fax: +49-228-3894-180

E-mail: iza@iza.org

Any opinions expressed here are those of the author(s) and not those of IZA. Research published in this series may include views on policy, but the institute itself takes no institutional policy positions.

The Institute for the Study of Labor (IZA) in Bonn is a local and virtual international research center and a place of communication between science, politics and business. IZA is an independent nonprofit organization supported by Deutsche Post Foundation. The center is associated with the University of Bonn and offers a stimulating research environment through its international network, workshops and conferences, data service, project support, research visits and doctoral program. IZA engages in (i) original and internationally competitive research in all fields of labor economics, (ii) development of policy concepts, and (iii) dissemination of research results and concepts to the interested public.

IZA Discussion Papers often represent preliminary work and are circulated to encourage discussion. Citation of such a paper should account for its provisional character. A revised version may be available directly from the author. 
IZA Discussion Paper No. 4780

February 2010

\section{ABSTRACT \\ The Role of Early-Life Conditions in the Cognitive Decline due to Adverse Events Later in Life*}

Cognitive functioning of elderly individuals may be affected by events such as the loss of a (grand)child or partner or the onset of a serious chronic condition, and by negative economic shocks such as job loss or the reduction of pension benefits. It is conceivable that the impact of such events is stronger if conditions early in life were adverse. In this paper we address this using a Dutch longitudinal database that follows elderly individuals for more than 15 years and contains information on demographics, socio-economic conditions, life events, health, and cognitive functioning. We exploit exogenous variation in early-life conditions as generated by the business cycle. We also examine to what extent the cumulative effect of consecutive shocks later in life exceeds the sum of the separate effects, and whether economic and health shocks later in life reinforce each other in their effect on cognitive functioning.

JEL Classification: $\quad$ I12, I10, J14, E32

Keywords: cognitive functioning, business cycle, bereavement, developmental origins, retirement, health, long-run effects, dementia

Corresponding author:

Gerard J. van den Berg

University of Mannheim

Department of Economics

L7, 3-5

68131 Mannheim

Germany

E-mail: gerard@uni-mannheim.de

\footnotetext{
* We thank participants at the AEA 2009 meetings, in particular Chris Paxson and Arie Kapteyn, for helpful comments, and Robert Scholte for useful contributions to the data analysis. The Longitudinal Aging Study Amsterdam (LASA) kindly allowed us to use their data. The LASA study is mostly financed by a long-term grant from the Netherlands Ministry of Health, Welfare and Sports.
} 


\section{INTRODUCTION}

Cognitive functioning of older individuals may be affected by events such as the loss of a (grand)child or partner or the onset of a serious chronic condition, and by negative economic shocks such as job loss or the reduction of pension benefits (see Orrell, Bebbington (1998); Clement, Darthout, Nubukpo 2003; Charles et al. 2006; van den Berg, Lindeboom and Portrait, 2002, 2006b, and references therein, for evidence). A move to an institution due to a need for assistance and care is likely to result in a further deterioration of mental or physical health as well. The death of the spouse and the concurrent changes in the lives of widowed persons have regularly been shown as most important sources of psychosocial stress - a factor associated with increased morbidity and mortality. Moreover, a small, but growing, body of evidence, suggests that adverse life events also may perpetuate poverty (Dercon, Hoddinott and Woldehanna, 2005, and references therein). As such, an indirect effect on health may be expected as well.

A recently emerging literature stresses the importance of a different set of causes of cognitive impairment at high ages. These causes originate earlier in life. Specifically, adverse conditions during the brain development early in life may affect cognitive development and cognitive functioning later in life. A number of studies strongly suggest a causal effect (see Factor-Litvak and Susser, 2004, for a recent overview). ${ }^{1}$ The developmental insults that have been studied are mostly nutritional, but exposure to high levels of stress or illness could also partly explain the observed link. Much of this evidence concerns cognitive outcomes among prime-aged adults. Recent evidence also suggests that exposure early in life to chemicals may lead or contribute to old ages neurological diseases, such as dementia, Alzheimer's disease or Parkinson (see Landrigan et al. 2005 and Miller, O'Callaghan 2008 and references therein) These older-age diseases are most important in ageing populations.

In the present paper we examine the role of economic conditions early in life on cognitive functioning at old ages. In particular, we aim to detect whether favorable conditions early in life mitigate the effects of adverse events later in life on cognitive ability (see Figure 1.1). It is conceivable that the impact of such events and shocks is weaker if conditions early in life were

\footnotetext{
${ }^{1}$ Schizophrenia is the most-studied severe cognitive disorder in this area of research (e.g. Susser and Lin 1992). Recent studies confirm the link between early prenatal insults and elevated risks of schizophrenia at adult ages for both genders (Saint-Clair, Xu and Wang, 2005, Brown and Susser, 2008, and references therein).
} 
favorable. For instance, initial economic positions may influence the extent to which persons can cope with the stressful event of bereavement or conflicts with important persons throughout their lives. Possibly, conditions early in life may also influence the impact of health-related events, like the onset of chronic diseases, on mental health. The literature on the developmental origins of diseases provides evidence that exposure to adverse (nutritional and pathogen) stimuli during the first stages of life may hinder the development of vital organs and immune system, with irreversible negative effects on health at high ages (see e.g. Barker, 1992). The "accumulation of risk" hypothesis in the literature on causal pathways in the life course states that health at old ages is the result of exposures to risk factors across the full elapsed lifetime (Kuh and BenShlomo, 2004). Education and other intermediate outcomes may exacerbate long-run effects. Individuals born in poor families may be less likely to go to school and to learn appropriately (Black, Devereux and Salvanes, 2005; Case, Fertig and Paxson, 2005). This may affect the extent to which they can deal with negative life events later in life.

Our empirical analysis focuses on the interplay between early-life (economic) conditions, adverse life events later in life, and cognitive functioning at old ages (see Figure 1.2). In a number of descriptive analyses, we inquire to which extent our indicators of early-life (economic) conditions are associated with cognitive status at old ages. More importantly, we investigate the causal cognitive effects of adverse events later in life, and we assess whether the causal effect of such events is stronger if conditions early in life were adverse. We use a Dutch longitudinal database that follows older individuals for more than 15 years and that contains detailed information on demographics, socio-economic background, health, and mortality.

Knowledge on the determinants of cognitive decline among the elderly facilitates the identification of groups of elderly who are particularly at risk. This is of great societal importance. Cognitive decline of an elderly family member may have a strong impact on the functioning of the household. In particular, the person involved may have increasing difficulties in making financial decisions (see Banks, O’Dea and Oldfield, 2009, and Smith, McArdle and Willis, 2009). With the increasing individualization of decisions on pensions and asset management, cognitive impairment may lead to substantial welfare loss for the household. Conversely, financial problems may enhance the cognitive decline, and we will address this in our study. 
It is also important from a policy point of view to know the determinants of cognitive decline. The costs of care for cognitively impaired individuals are high and are expected to increase in the upcoming decades. The theory of cognitive reserve suggests that a decline in cognitive ability can be delayed or mitigated by enhancing brain reserve capacity; see Kuh and Ben-Shlomo (2004). Adverse events in the life of elderly individuals are readily observed by caretakers and are therefore a potentially informative red flag for an upcoming decline. If early-life conditions are found to affect the magnitude of the cognitive effects of major adverse events later in life, then it may be worthwhile to focus the monitoring on those who were subject to such events and who were born under adverse conditions.

The empirical analysis needs to address the potential endogeneity of early-life conditions as well as the potential endogeneity of the occurrence of adverse life events at higher ages. We deal with the latter by exploiting repetitive observations of cognitive ability measures. Specifically, we estimate fixed-effects panel data equations with cognitive ability measures as outcomes. This methodological approach is particularly suitable to study health effects of shocks and singular events that occur between successive individual observations (and their interaction with early-life conditions). We deal with the early-life conditions endogeneity problem by using contextual (aggregate) indicators of early-life conditions that are exogenous. Specifically, we use business cycle fluctuations in the birth year. This follows van den Berg, Lindeboom, and Portrait (2006a) and van den Berg, Doblhammer and Christensen (2010), who focus on the effects of the prevailing economic conditions at birth on individual mortality rates and cause-specific mortality rates later in life. The basic idea is that birth in a recession causes adverse economic conditions in many households. This may in turn lead to a low quality and/or quantity of nutrition, to adverse housing conditions, and to an enhanced stress level in the household. The business cycle is plausibly not affecting late-life health outcomes in other ways than through its effect on health and abilities around birth. An effect of the business cycle on late-life health outcomes is then evidence of a causal effect of early-life conditions on late-life health. ${ }^{2}$

The outline of the paper is as follows. Section 2 presents the data. Section 3 contains the results. Section 4 concludes.

\footnotetext{
${ }^{2}$ Van den Berg, Lindeboom, and Portrait (2006a) and van den Berg, Doblhammer and Christensen (2010) find significant causal effects on mortality and on cardiovascular mortality, respectively. Similar methodological approaches are used by Doblhammer (2004), who demonstrates that survival at ages older than 50 is significantly affected by the season of birth, and by Bengtsson and Lindstrom (2000, 2003), who use variation in food prices and infant mortality early in life. These studies have in common that they exploit modest fluctuations in early-life conditions, and therefore the results are not driven by extreme events like severe famines or epidemics.
} 


\section{DATA AND MEASURES}

\subsection{THE LASA DATA}

The Longitudinal Aging Study Amsterdam (LASA) is an ongoing study which follows a representative sample of Dutch older institutionalized and non-institutionalized individuals born in 1908-1937. The design and purposes of the LASA study are described in detail elsewhere (Deeg et al., 1994, 1998). Five waves are currently available, hold in 1992-93, 1995-96, 1998-99, 2002-03 and 2005-06. Note that there are no refreshment sample after wave I. Table 1 describes the non-response at successive waves. Individuals can leave the sample for several reasons. About $75 \%$ of the respondents who leave the sample between two waves died. $14 \%$ of them refused to participate in the study anymore, $6 \%$ were too frail to participate, and $3 \%$ could not be contacted.

Respondents with a telephone or a short interview are excluded from the study as no sufficient information is available on them to address the research question.

\subsection{HEALTH MEASURES}

Table 2 provides summary measures on health and demographic measures. We measure in our analyses the cognitive status by the Mini Mental State Examination (MMSE) score (Folstein et al. 1995). The MMSE score is a widely used method for assessing cognitive status of older individuals. It provides a total score that places the individual on a scale of cognitive functioning. The lower the score, the higher the cognitive impairment. The variable ranges between 0 and 30 and usually a cut-off point of 23/24 is used to indicate cognitive impairment. Figure 2.1. provides the distribution of the MMSE scores at waves I-V. The MMSE score is positively associated with the level of education.

Apart from the MMSE the data also contain a measure of fluid intelligence. Fluid intelligence is defined as the ability to deal with new information. Contrary to crystallized intelligence (or knowledge), fluid intelligence is particularly sensitive to decrements associated with aging (Horn, 1985; Smits et al., 1997). Fluid intelligence is assessed with the Raven Coloured Progressive Matrices (RCPM, Raven, 1995). Both the MMSE variable and the raven test score 
are relevant for financial decision making. Our analyses (to be discussed in section 3) will focus on the results for the MMSE analyses. However, we also performed all analyses on the Raven test score variable. The results of these analyses (not reported here, but available upon request) were very similar.

The CES-D indicator is used to measure emotional functioning of older individuals. The total score ranges from 0 to 60 and respondents with scores higher than 16 display clinically relevant symptoms of depressions (Radloff, 1977).

Physical health is measured by indicators on functional limitations, disability, and on the presence of seven most important chronic diseases. Functional limitations are measured in the LASA study by self-reports on mobility activities in daily life (McWhinnie, 1981). These selfreports include the ability of respondents to: (1) cut one's own toenails, (2) walk up and down a 15-steps staircase without stopping, and (3) make use of private or public transportation (McWhinnie 1981; van Sonsbeek 1988). The score takes on value 0 when all items are performed without any difficulty, and 1,2, and 3, when 1,2, or 3 items respectively are performed with difficulty. Disability is measured by asking the respondents whether he or she experiences difficulties in performing daily activities because of health problems. The variable can take the value " 1 " if health problems severely affect daily activities, the value " 2 " if health problems slightly affect daily activities and the value "3" when the respondent does not experience any difficulties with daily activities because of health problems. Finally, the presence of chronic diseases is assessed by asking the participants whether they have or have had any of the following diseases: chronic obstructive pulmonary diseases (COPD), heart diseases, arteriosclerosis, diabetes, stroke, cancer, and arthritis (osteoarthritis and rheumatoid arthritis).

Table 2 and Figure 2.1 show that, at wave I, about two-third of the LASA respondents have no physical limitations and that about $4 \%$ of the population suffer from severe cognitive impairment and is clinically depressed.

\subsection{DEMOGRAPHIC AND SOCIO-ECONOMIC CHARACTERISTICS}

In addition to gender and age, the following individual characteristics are included in our analyses: marital status, urbanisation degree of the municipality where the respondent lives (categorical variable ranging from "1"= low to " $5 "=$ high), education (categorical variable 
ranging from "1"= elementary education not completed to "9"= university education), income and the prestige code of the longest occupation. Income was ascertained by asking the respondents to assign their monthly net income to classes ranging from less than $€ 454$ to more than $€ 1.818$. The total income of the respondent and his/her possible partner is asked and a correction factor equal to 0.7 is applied if the respondent has a partner (adult equivalent adjusted). Missing values for income were relatively frequent (about 16\%). The occupational prestige of the longest job is measured using the classification described in Sixma and Ultee (1983) (categorical variable ranging from $0=$ “never had job" till $87=$ " high prestige").

\subsection{LIFE EVENTS}

Table 3 presents frequencies of the life events occurring between successive waves. $4 \%$ of the respondents on average lose their spouse between successive waves. A negligible number of respondents divorced during the observation window. Furthermore, with respect to chronic diseases, arthritis, and heart diseases are the most commonly observed chronic conditions and we also observe their onset (or relapse) most frequently. On average $10 \%$ of the respondents experience a surgery between two waves. A substantial fraction of the respondents loses at least a parent, a brother, a sister, a child or a grand child during the observation period. Illness of partner and relatives is also a common phenomenon. Finally, the onset of severe financial problems, having a conflict with an important person and being a victim of a crime is observed for a small, yet non-negligible, fraction of respondents.

\subsection{MACRO INDICATORS}

A Hodrick-Prescott filter with smoothing parameter 500 is used to decompose log annual per capita GDP into a trend and a cyclical component (Hodrick and Prescott 1997). The GDP data are from Maddison (2003). Figure 2 shows the $\log ($ real annual per capita GDP) and the detrended series. The cyclical development is in line with important historical events. First, there is a severe recession around the end of World War I and at the arrival of the Influenza Pandemic (October November 1918) (Vugs 2002). Second, the Dutch economy developed positively alongside a global economic upturn in the 1920s, which resulted in an increase of the average living standards. Third, there is a clear recession during the Great Depression, which reached the Netherlands relatively lately (1931) and lasted unusually long (until about 1936). This was partially caused by a refusal of the Dutch government to let the gold standard go. This recession 
had substantial impact on the daily-life of civilians. For instance, the number of unemployed individuals rose from 50.000 to 414.500 between 1929 and 1936 (Beishuizen and Werkman 1968).

We may accordingly define two intervals each consisting of a boom and a subsequent recession (group A (1909 - 1921) and group B (1924 - 1936)). The respondents belonging to these two intervals are selected for some simple explorative analyses (Table 4, to be discussed below). We construct three measures for the state of the business cycle at birth. First, the value of a Boom dummy equals one when log GDP is above its trend level and zero otherwise. A second variable corresponds to the actual value of the cyclical component. This variable is, in contrast to the recession dummy, able to take the size of booms and recessions into account. Third, two dummy variables measuring the peak years (years belonging to the $4^{\text {th }}$ quartile of the cyclical component) and trough years (years belonging to the $1^{\text {st }}$ quartile of the cyclical component) of the boom and recession, respectively.

Table 4 below present the results of the first exploratory analyses. The maximum of the MMSE score is equal to 30 and we transform the cognition score to the logarithm of 31- MMSE score. This is to assure that the results do not depend too much on extreme low values of the MMSE score. High values are therefore associated with bad cognitive functioning, low values with good cognitive functioning. Age measured exact up to days and is recorded at the date of the interview. His explains why both the cohort year and the age can be included in the analyses of Table 4. We also ran the same regressions, while excluding the cohort variable from the analyses. The results (available upon request) were virtually identical to those reported in Table 4 . The results in Table 4 indicate that the state of the business cycle may have an effect on cognitive functioning at later ages. More specifically, those born in a boom have better cognitive health and those born trough years have worse cognitive health.

\section{EMPIRICAL ANALYSES AND RESULTS}

In this section we perform analyses based on the entire sample and the cognitive score for all waves. We start with simple regressions where we pool the panel information. Subsequently, we perform panel data analyses with fixed effects, where the outcome is the cognitive score, and the 
explanatory variables include the shocks since the previous wave of the panel, and their interactions with the early-life indicators.

Our range of empirical analyses is somewhat restricted by the fact that the sample is drawn from the stock of those alive in 1992 who were born in 1908-1937. First, notice that this sample excludes those born in those years who have died before 1992. The association of early-life effects and later events may then be weakened because of dynamic selection. However, with panel data analyses one can deal with this by assuming that the dynamic selection is driven by the same unobservable as the fixed effect in the outcome of interest.

Secondly, there is a negative linear association in the sample between age in 1992 and birth year. Any restriction on birth years thus necessarily entails a restriction on the age window. For example, a restriction to early birth cohorts entails a restriction to older individuals. This complicates a direct comparison of favorable and unfavorable birth cohorts as in e.g. van den Berg, Lindeboom and Portrait (2006a). In the case of shocks at higher ages, it also means that among the elderly we only observe shocks at very high ages, whereas among the younger respondents most shocks are observed at (relatively) lower ages only.

Tables 5a present the results of a model where the cognitive score is related to a range of observed demographic characteristics, the occurrence of life events and the cyclical components of the business cycle at the time of birth. Table $5 \mathrm{~b}$ presents the results of the same model, but in this specification the cyclical component is replaced by the peak and trough values of the cyclical component (the values of the first quartile and the fourth quartile of the cyclical component). The dependent variable is the transformed cognitive score (logarithm of 31 - MMSE score) and therefore negative coefficients are therefore associated with better cognitive outcomes. Both tables include three different specifications of the levels equation. The first specification (I) includes a base specification where the onset of new chronic conditions are aggregated into a single indicator. In the second column (specification II) we add the lagged dependent variable. In the third specification (III) we extend on specification II by making a distinction between the different kinds of health shocks. We start with a brief discussion of the results in Table 5a.

We find strong effects of the demographic variables across all specifications and most of these effects are as expected. For instance, age has a positive and significant effect, implying that cognitive functioning decreases with age. It is remarkable to see that the age coefficient only 
reduces slightly in magnitude when the lagged dependent variable is added in the specification. The negative education coefficient indicates that those with more years of education have higher cognitive skills at later ages. Females also have higher cognitive skills. The effect of education and gender is reduced to about half when the lagged dependent variable is added to the specification, but these two variables remain strongly significant.

Concerning the life events variables, no effects are found for a bereavement indicator and for the number of new chronic conditions. We do however find effects for experiencing the death of family members (parents, siblings and (grand)children) and illness of a family member or relative. The latter effect indicates that an illness of a family member or relative is associated with better cognitive outcomes. It remains to be seen whether this somewhat surprising effect remains in the fixed effects specifications (to be discussed below). However, an illness of a close relative may involve the provision of care by the respondent and this in turn may have a (temporary) health preserving effect. In earlier work (van den Berg, Lindeboom, Portrait 2002) we found strong negative effect on the mental health of the illness of a family member or a relative. We find some effect for an indicator whether the individual experienced financial difficulties in the past period, but this effect is only significant at the $10 \%$ level in the static model. Finally, the onset of new chronic conditions does not have an impact in either the static (I) or the dynamic model (II), but we do find a significant effect of a stroke on cognition (specification III).

The coefficient of the cyclical component of the business cycle at birth has the expected sign, but it is not significant at the standard levels. We do find significant effects for the peak variable in Table $5 \mathrm{~b}$ and the effect is in the expected direction: those born in peak years have better cognitive outcomes. The effects of the other demographic and life events variables in Table $5 \mathrm{~b}$ are similar to those in Table 5a.

Tables 6 and 7 report the results of a model in first differences of the transformed cognitive score and therefore allows for unobserved individual fixed effects. This also means that additive effects of the business cycle indicators cancel from the specification. The first column (specification I) of Table 6 reports the results for the full sample, the second and the third column are estimated on samples of individuals who are born in a period where the cyclical component of the GDP is negative ('Recession') and positive ('Boom'), respectively. The sample sizes did not permit us to estimate separate models for 'peak' and 'trough' years. 
The results reported in column 1 are in line with the results of the life events variables presented in Tables 5a and 5b. A stroke has a strong effect on the cognitive health score and the positive coefficient indicates that cognitive skills deteriorate after the onset of a stroke. The negative coefficient of the 'illness of a family member or a relative' also remains when we control for unobserved fixed effects and implies that cognitive skills improve after the onset of this life event. The results in column 1 also show us somewhat surprisingly that the onset of Arteriosclerosis has a positive impact on cognitive skills, but this effect is only significant at the $10 \%$ level.

We calculated the fixed effects of this model and regressed these on a set of time-constant variables. The results of this exercise are reported in Table 8. Of course it is difficult to give a pure causal interpretation to the coefficients. The results indicate that those born in peak years have better cognitive skills. The effect of the demographic variables is (as expected) very similar to those in Tables 5a and 5b. The negative birth year variable indicates that those born later have better cognitive skills. Furthermore we find better cognitive skills for females, those who are married and those who have more years of education. Again the stroke indicator (defined here as whether or not one has experienced the event prior to the first wave) has a strong impact on the fixed effect. The positive coefficient indicates that the stroke is associated with worse cognitive skills.

The results of column 1 in Table 6 provide an aggregate effect of the life events variables. In column 2 and 3 of Table 6 and in Table 7 we estimated the model on separate sub-samples. With these analyses we aim to detect whether individuals exposed to different conditions early in life respond differently to life events later in life. Also, earlier work (e.g. Koupil et al., 2007) shows that adverse conditions earlier in life may have differential effects for males and females. The results of columns 2 and 3 of Table 6 and the results of Table 7 show that the impact of shocks later in life may vary with respect to conditions that individuals have been exposed to earlier in life and that this differs for men and women. More specifically, column 2 and 3 of Table 6 reveal that the effect of a stroke is driven by those who are born in a recession. The stroke has no impact on the cognitive skills for those who are born under more favourable conditions at the time of birth. We furthermore learn from columns 2 and 3 of Table 6 that the positive effect of the 'illness of a family member or relative' variable is entirely driven by those born in a boom: the (temporary) health preserving effect of giving care is only present for those born in favorable 
economic conditions. The results of Table 6 also show that the 'death of parents, siblings and (grand)children' has a negative impact on cognitive skills. A further disaggregation with respect to gender shows that the "stroke" effect and the effect of a death of a relative is primarily important for the development of the cognitive skills of women born in recessions. The health preserving effect of an "illness of a family member or relative" is present for both men and women born in booms.

All analyses were repeated with a different measure of cognitive functioning, namely the Raven test score (see Section 2). All analyses of Tables 4 to 8 were repeated with this variable. The results (available upon request) were very similar.

\section{CONCLUSIONS}

Individuals who experience a stroke at high ages witness a strong subsequent decline in cognitive abilities. We find that this decline is stronger if the individual experienced adverse economic conditions around his or her birth. Specifically, the cognitive abilities of individuals born in a recession suffer more strongly from a stroke than the cognitive abilities of individuals born in years with a favorable business cycle. This suggests that strokes are more devastating if the individual is born under adverse conditions or that the ability to recover from strokes is more limited if birth was under adverse conditions. This finding is consistent with the literature on the "developmental origins" of cardiovascular diseases. Lawlor, Ben-Shlomo and Leon (2004) survey the strong evidence on the negative association between birth size on the one hand, and cerebrovascular accidents (CVA) outcomes (i.e. strokes) later in life on the other hand. Basically, individuals with low birth weight experience strokes earlier than other individuals. Of course, a stroke has stronger immediate effects on the functioning of parts of the brain than many other cardiovascular diseases. What we find is that, for individuals born under adverse conditions, the cognitive effects of strokes are larger.

We also find significantly stronger negative cognition effects of surgery and illness or death of a family member if the individual was born under adverse conditions. At the same time, we do not observe an effect of the presence of financial problems on the rate of cognitive decline. Moreover, the latter applies to individuals born under favorable as well as unfavorable conditions. A major difference between bereavement and illness of family members on the one 
hand and financial shocks on the other hand is that the former are typically beyond the control of the individual. Apparently, adverse events that are hard to influence lead to larger cognitive declines and are harder to compensate through favorable early-life conditions. As a final conclusion we note that, in general, the effects that we find are stronger for women than for men. 


\section{LITERATURE}

Banks J, O’Dea C, Oldfield, Z (2009) “Cognitive function, numeracy and retirement saving trajectories", Working paper, Institute for Fiscal Studies.

Barker DJP (1992) "Foetal and infant origins of adult diseases", London BMJ Publishing Group.

Beishuizen J, Werkman E (1968) Nederland in de crisistijd 1929-1939. A.W. Slijthof: Leiden.

Bengtsson T., Lindström M (2000), Childhood misery and disease in late life: The effects on mortality in old age of hazards experienced in early life, southern Sweden, 1760-1894, Population Studies 54, 263-277.

Bengtsson T, Lindstrom M (2003) "Airborne infectious diseases during infancy and mortality in later life in southern Sweden, 1766-1894”, International Journal of Epidemiology 32:286294.

van den Berg GJ, Doblhammer G, Christensen, K. (2010) "Being born under adverse economic conditions leads to a higher cardiovascular mortality rate later in life: Evidence based on individuals born at different stages of the business cycle", Demography, forthcoming.

van den Berg GJ, Lindeboom M, Portrait F (2002) “An econometric analysis of the mental-health effects of major events in the life of older individuals" Health Economics 11:505-520.

van den Berg GJ, Lindeboom M, Portrait F (2006a) "Economic conditions early in life and individual mortality", American Economic Review 96:290-302.

van den Berg GJ, Lindeboom M, Portrait F (2006b) “The effect of conjugal bereavement on health status and mortality of older individuals", Working paper.

Black SE, Devereux PJ, Salvanes K (2005) "From the Cradle to the Labor Market? The Effect of Birth Weight on Adult Outcomes", NBER working paper No 11796.

Brown AS, Susser ES (2008) "Prenatal Deficiency and Risk of Adult Schizophrenia" Schizophrenia Bulletin 34(6) 1054-63

Case A, Fertig A, Paxson C (2005) "The lasting impact of childhood health and circumstance", Journal of Health Economics 24:365-389.

Case A, Paxson C (2009) "Early life Health and Cognitive Function in Old Age", The American Economic Review papers and proceedings of the 121 Meeting of the American Economic Association, Vol 99, no 2, pp104-109.

Charles E, Bouby-Serieys V, Thomas P, Clément JP (2006) "Links between life events, traumatism and dementia; an open study including 565 patients with dementia",L'Encéphale (in French) 32:746-52. 
Clement JP, Darthout N, Nubukpo P (2003) "Life events, Personality and Dementia", Psychologie \& Neuropsychiatrie du Vieillissement (in French) 1(2) :129-38.

Deeg DJH, Westerdorp de Serière MW (1994) Autonomy and well-being in the aging population, report from the Longitudinal Aging Study Amsterdam 1992-1993, VU University Press Amsterdam

Deeg DJH, Beekman ATF, Kriegsman DMW, Westerdorp de Serière (1998) Autonomy and well-being in the aging population, report from the Longitudinal Aging Study Amsterdam 1992-1996, VU University Press Amsterdam

Dercon S, Hoddinott J, Woldehanna T (2005) "Vulnerability and Shocks in 15 Ethiopian Villages, 1999-2004", CRSP working paper, University of Wisconsin-Madison.

Doblhammer G (2004) “The late legacy of very early life.” Demographic Research Monographs, Rostock: Max Planck Institute for Demographic Research.

Factor-Litvak P, Susser E (2004) “A life course approach to neuropsychiatric outcomes” in Kuh D, Ben-Shlomo Y "A life course approach to chronic disease epidemiology", 2nd edition, Oxford University Press, Oxford.

Folstein, MF, Folstein SE, McHugh PR (1995) Mini-mental state: a practical method for grading the cognitive state of patients for the clinician, Journal of Psychiatric Research, vol. 12.

Hodrick R, Prescott EC (1997) Postwar U.S. business cycles: an empirical investigation. Journal of Money, Credit and Banking, 29, 1-16.

Horn, JL (1985) Remodeling old models of intelligence. In Wolman BB (ed.), Handbook of intelligence. Wiley, New York.

Koupil I, Shestov DB, Sparén P, Plavinskaja S, Parfenova N, Vågerö D (2007) "Blood Pressure, Hypertension and Mortality from Circulatory Disease in Men and Women who Survived the Siege of Leningrad”, European Journal of Epidemiology 22:223-234.

Kuh D, Ben-Shlomo Y (2004) “A life course approach to chronic disease epidemiology", 2nd edition, Oxford University Press, Oxford.

Landrigan PJ, Sonawane B, Butler RN, Trasande L, Callan R, Droller D (2005) "Early environmental origins of neurodegenerative disease in later life" Environmental Health Perspectives 113(9):1230-33.

Lawlor DA, Ben-Shlomo Y, Leon DA (2004), "Pre-adult influences on cardiovascular disease", in: D. Kuh and Y. Ben-Shlomo (eds.), A life course approach to chronic disease epidemiology, Oxford University Press, Oxford. 
Lumey LH, Stein AD, Kahn AS, van der Pal-de Bruin KM, Blauw GJ, Zybert PA, Susser ES (2007) "Cohort Profile: The Dutch Hunger Winter Families Study" International Journal of Epidemiology 36(6):1196-1204.

Maddison A. (2003) The world economy: historical statistics. Development Centre Studies: OECD.

Miller DB, O'Callaghan JP (2008) “Do early-life insults contribute to the late-life development of Parkinson and Alzheimer diseases?"Metabolism 57(2):S44-49.

Orrell L, Bebbington P (1998) "Life events and cognition in dementia" Aging and Mental Health 2(1):53-59.

Radloff LS (1977) The CES-D scale: a self-report depression scale for research in the general population, Applied Psychological Measurement, vol. 1.

Raven JC (1995) Manual for the Coloured Progressive Matrices (revised). Windsor, UK: NFRENelson.

Saint-Clair D, Xu M, Wang P et al. (2005) "Rates of adult schizophrenia following prenatal exposure to the Chinese Famine of 1959-61" JAMA 294:557-562.

Sixma H, Ultee WC (1983) Occupational prestige score for the Netherlands in the eighties (in Dutch). Mens \& Maatschappij 58:360-382.

Smith JP, McArdle JJ, Willis R (2009), "Financial Decision Making and Cognition in a Family Context", Working paper, RAND Corporation.

Smits CHM, Smit JH, Van den Heuvel N, Jonker C (1997) "Norms for an abbreviated Raven's Coloured Progressive Matrices in an older sample" Journal of Clinical Psychology, 53: 687697.

Sonsbeek van JLA (1988) Methodological and substantial aspects of the OECD questionnaire regarding long-term limitations in physical functioning (in Dutch). Maandbericht Gezondheid (Central Bureau of Statistics), Netherlands 6:4-17.

Susser ES, Lin SP (1992) "Schizophrenia after prenatal exposure to the Dutch Hunger Winter of 1944-45” Arch Gen Psychiatry 49:983-8.

Vugs R. (2002) In veel huizen wordt gerouwd. De Spaanse griep in Nederland. Aspekt: Soesterberg. (in Dutch).

McWhinnie JR (1981) Disability assessment in population surveys: Results of the OECD common development effort. Revue Epidémiologique et Santé Publique 29:413-419 
Table 1: SPECIFICATION OF THE NON-RESPONSE IN THE LASA DATA

\begin{tabular}{l|r|r|r|r|r}
\hline & Wave I & Wave II & Wave III & Wave IV & Wave V \\
\hline Data present: & $3,107:$ & $2,545:$ & $2,076:$ & $1,691:$ & $1,257:$ \\
$\quad$ Normal & 2,925 & 2,204 & 1,717 & 1,340 & 932 \\
Short / Telephone interview & 182 & 341 & 359 & 351 & 325 \\
Deceased & & 417 & 344 & 290 & 355 \\
Refusals / Ineligible / Not contacted & & 145 & 125 & 95 & 79 \\
\hline
\end{tabular}


$\underline{\text { Table } 2}$ - MEAN / FREQUENCY OF RELEVANT VARIABLES AT WAVE I

\begin{tabular}{|c|c|c|}
\hline VARIABLES & SCORE & Mean / Frequency \\
\hline Chronic diseases (in \%) & $\begin{array}{r}\text { no difficulty } \\
\text { one with difficulty } \\
\text { two with difficulty } \\
\text { three with difficulty } \\
\text { no } \\
\text { yes, slightly } \\
\text { Yes severely } \\
\text { COPD } \\
\text { Heart diseases } \\
\text { Arteriosclerosis } \\
\text { Diabetes } \\
\text { Stroke } \\
\text { Cancer } \\
\text { Arthritis } \\
\text { mean }\end{array}$ & $\begin{array}{r}26.8 \\
8.0 \\
58.6 \\
19.1 \\
11.7 \\
10.7 \\
68.0 \\
19.1 \\
12.9 \\
11.6 \\
19.6 \\
9.8 \\
7.9 \\
5.7 \\
9.3 \\
34.8 \\
0.98\end{array}$ \\
\hline $\begin{array}{r}\text { DEMOGRAPHICS } \\
\text { Mean age } \\
\text { Female (in \%) } \\
\text { Marital status (in \%) } \\
\text { Urbanisation level (Low) } \\
\text { Education (in \%) } \\
\text { Monthly net income (in \%) }\end{array}$ & $\begin{array}{r}\text { never married } \\
\text { married } \\
\text { divorced } \\
\text { widowed } \\
\\
\text { elementary or less } \\
\text { intermediate } \\
\text { high } \\
\text { missing } \\
<€ 681 \\
€ 682-€ 1.136 \\
€ 1.137-€ 1.818 \\
>1.818\end{array}$ & $\begin{array}{r}70.8 \\
51.5 \\
6.1 \\
62.5 \\
5.2 \\
26.2 \\
48.5 \\
33.9 \\
44.2 \\
11.4 \\
16.1 \\
18.9 \\
32.9 \\
21.0 \\
11.1 \\
36.1\end{array}$ \\
\hline
\end{tabular}


Table 3 - FREQUENCY OF LIFE EVENTS

\begin{tabular}{|c|c|c|c|c|}
\hline BETWEEN & WAVE I \& II & WAVE II \& III & WAVE III \& IV & WAVE IV \& V \\
\hline Widowed (in \%) & 4.4 & 3.5 & 3.4 & 3.4 \\
\hline Divorced (in \%) & 0.1 & 0.1 & 0.1 & 0 \\
\hline $\begin{array}{l}\text { Incidence or relapse Chronic } \\
\text { diseases (in \%): }\end{array}$ & & & & \\
\hline Respiratory diseases & 2.5 & 3.0 & 2.1 & 1.8 \\
\hline Heart diseases & 5.6 & 4.8 & 4.8 & 5.7 \\
\hline Arteriosclerosis & 3.0 & 2.2 & 3.1 & 2.4 \\
\hline Diabetes & 1.7 & 2.0 & 2.1 & 3.5 \\
\hline CVA (Stroke) & 2.8 & 2.2 & 2.6 & 3.3 \\
\hline Arthritis & 11.1 & 8.9 & 7.5 & 8.7 \\
\hline Cancer & 3.6 & 3.8 & 3.6 & 4.6 \\
\hline Surgery (in \%) & 9.4 & 10.1 & 9.2 & 12.7 \\
\hline $\begin{array}{l}\text { Death parent, brother, sister, child } \\
\& \text { grand-child (in \%) }\end{array}$ & 22.1 & 8.6 & 18.5 & 16.0 \\
\hline Illness partner \& relatives (in \%) & 36.4 & 35.4 & 26.6 & 24.9 \\
\hline $\begin{array}{l}\text { Financial problems (in \%) } \\
\text { Conflict \& Victim of crime (in \%) }\end{array}$ & 10.1 & 7.5 & 6.7 & 5.7 \\
\hline $\begin{array}{l}\text { Move to Semi-independent House } \\
\text { Institution or hospital (in \%) }\end{array}$ & 4.9 & 4.2 & 4.0 & 5.2 \\
\hline
\end{tabular}


Table 4 EFFECT OF THE BUSINESS CYCLE AT BIRTH ON COGNITION AT WAVE I

\begin{tabular}{lrrr}
\hline Variables & Model I & Model II & Model III \\
\hline Year of birth & 0.053 & 0.055 & 0.053 \\
& $(0.035)$ & $(0.035)$ & $(0.035)$ \\
Age & $0.080^{* *}$ & $0.080^{* *}$ & $0.081^{* *}$ \\
& $(0.035)$ & $(0.035)$ & $(0.035)$ \\
Boom dummy & $-0.056^{* *}$ & & \\
& $(0.028)$ & & \\
Cyclical component of business cycle & & -0.232 & \\
& & $(0.181)$ & \\
Trough years (1 ${ }^{\text {st }}$ quartile of cyclical component) & & & $0.076^{*}$ \\
& & & $0.040)$ \\
Peak years (4th quartile of cyclical component) & & & 0.013 \\
& & & $(0.034)$ \\
Constant & $-5.664^{*}$ & $-5.740^{*}$ & $-5.745^{*}$ \\
& $(3.202)$ & $(3.205)$ & $(3.203)$ \\
Observations & 1937 & 1937 & 1937 \\
R-squared & 0.118 & 0.117 & 0.118 \\
\hline
\end{tabular}

Cognition is measured by $\log (31-$ MMSE). High values are associated with worse cognition.

Robust standard errors in parentheses. $* * * \mathrm{p}<0.01, * * \mathrm{p}<0.05, * \mathrm{p}<0.1$ 
Table 5a LEVELS EQUATIONS MMSE CORRECTED FOR VALUE OF CYCLICAL INDICATOR GDP AT BIRTH (POOLED DATA)

\begin{tabular}{|c|c|c|c|}
\hline VARIABLES & Model I & Model II & Model III \\
\hline Lagged $\log (31-\mathrm{MMSE})$ & & $\begin{array}{r}0.470 * * * \\
(0.014)\end{array}$ & $\begin{array}{r}0.469 * * * \\
(0.014)\end{array}$ \\
\hline Year of birth & $\begin{array}{r}-0.015 * * * \\
(0.003)\end{array}$ & $\begin{array}{r}-0.006 * * * \\
(0.002)\end{array}$ & $\begin{array}{r}-0.007 * * * \\
(0.002)\end{array}$ \\
\hline Age & $\begin{array}{r}0.015^{* * *} * \\
(0.003)\end{array}$ & $\begin{array}{r}0.013 * * * \\
(0.003)\end{array}$ & $\begin{array}{r}0.013 * * * \\
(0.003)\end{array}$ \\
\hline Number of chronic conditions at wave I & $\begin{array}{r}0.015 \\
(0.010)\end{array}$ & $\begin{array}{r}0.011 \\
(0.007)\end{array}$ & $\begin{array}{r}0.010 \\
(0.007)\end{array}$ \\
\hline Level of Education & $\begin{array}{r}-0.089 * * * \\
(0.005)\end{array}$ & $\begin{array}{r}-0.047 * * * \\
(0.004)\end{array}$ & $\begin{array}{r}-0.047 * * * \\
(0.004)\end{array}$ \\
\hline Married & $\begin{array}{r}-0.015 \\
(0.021)\end{array}$ & $\begin{array}{r}-0.004 \\
(0.020)\end{array}$ & $\begin{array}{r}-0.005 \\
(0.020)\end{array}$ \\
\hline Female & $\begin{array}{r}-0.102 * * * * \\
(0.021)\end{array}$ & $\begin{array}{r}-0.059 * * * \\
(0.014)\end{array}$ & $\begin{array}{r}-0.059 * * * \\
(0.014)\end{array}$ \\
\hline \multicolumn{4}{|l|}{ Life events (onset) } \\
\hline Bereaved & $\begin{array}{l}-0.008 \\
(0.032)\end{array}$ & $\begin{array}{r}0.011 \\
(0.029)\end{array}$ & $\begin{array}{r}0.013 \\
(0.029)\end{array}$ \\
\hline Death of a parent, sibling, (grand)child & $\begin{array}{c}0.031^{*} \\
(0.017)\end{array}$ & $\begin{array}{c}0.023^{*} \\
(0.014)\end{array}$ & $\begin{array}{r}0.023 \\
(0.014)\end{array}$ \\
\hline Illness of partner or relatives & $\begin{array}{r}-0.121 * * * \\
(0.016)\end{array}$ & $\begin{array}{r}-0.088^{* * * *} \\
(0.013)\end{array}$ & $\begin{array}{r}-0.087 * * * \\
(0.013)\end{array}$ \\
\hline Financial problems & $\begin{array}{c}0.106^{*} \\
(0.059)\end{array}$ & $\begin{array}{r}0.054 \\
(0.046)\end{array}$ & $\begin{array}{r}0.060 \\
(0.046)\end{array}$ \\
\hline CVA (stroke) & & & $\begin{array}{r}0.114 * * * \\
(0.040)\end{array}$ \\
\hline Heart disease & & & $\begin{array}{r}-0.006 \\
(0.025)\end{array}$ \\
\hline Respiratory diseases & & & $\begin{array}{r}-0.031 \\
(0.035)\end{array}$ \\
\hline Arteriosclerosis & & & $\begin{array}{c}-0.058^{*} \\
(0.034)\end{array}$ \\
\hline Diabetes & & & $\begin{array}{r}0.034 \\
(0.042)\end{array}$ \\
\hline Cancer & & & $\begin{array}{r}-0.036 \\
(0.029)\end{array}$ \\
\hline Number of chronic conditions & $\begin{array}{r}-0.017 \\
(0.012)\end{array}$ & $\begin{array}{r}-0.006 \\
(0.011)\end{array}$ & \\
\hline \multicolumn{4}{|l|}{ Conditions at birth } \\
\hline Cyclical component of business cycle & $\begin{array}{r}-0.183 \\
(0.156)\end{array}$ & $\begin{array}{l}-0.097 \\
(0.102)\end{array}$ & $\begin{array}{r}-0.100 \\
(0.101)\end{array}$ \\
\hline Constant & $\begin{array}{r}0.903 * * * \\
(0.279)\end{array}$ & $\begin{array}{r}0.097 \\
(0.242) \\
\end{array}$ & $\begin{array}{r}0.134 \\
(0.242) \\
\end{array}$ \\
\hline Observations & 6490 & 6478 & 6481 \\
\hline R-squared & 0.227 & 0.380 & 0.382 \\
\hline
\end{tabular}

Cognition is measured by $\log (31-\mathrm{MMSE})$. High values are associated with worse cognition $* * * \mathrm{p}<0.01, * * \mathrm{p}<0.05, * \mathrm{p}<0.1$ Robust clustered standard errors in parentheses 
Table 5b LEVELS EQUATIONS MMSE CORRECTED FOR PEAK AND TROUGH YEARS $\left(1^{\mathrm{ST}}\right.$ AND $4{ }^{\mathrm{TH}}$ QUARTILE OF THE CYCLICAL COMPONENT) AT BIRTH (POOLED DATA)

\begin{tabular}{|c|c|c|c|}
\hline VARIABLES & Model I & Model II & Model III \\
\hline Lagged $\log (31-\mathrm{MMSE})$ & & $\begin{array}{r}0.469 * * * \\
(0.014)\end{array}$ & $\begin{array}{r}0.469 * * * \\
(0.014)\end{array}$ \\
\hline Year of birth & $\begin{array}{r}-0.014 * * * \\
(0.003)\end{array}$ & $\begin{array}{r}-0.006^{* *} \\
(0.002)\end{array}$ & $\begin{array}{r}-0.006 * * \\
(0.002)\end{array}$ \\
\hline Age & $\begin{array}{r}0.015^{* * *} * \\
(0.003)\end{array}$ & $\begin{array}{r}0.014 * * * \\
(0.003)\end{array}$ & $\begin{array}{r}0.013 * * * \\
(0.003)\end{array}$ \\
\hline Number of chronic conditions & $\begin{array}{r}0.016 \\
(0.010)\end{array}$ & $\begin{array}{c}0.011 * \\
(0.007)\end{array}$ & $\begin{array}{r}0.010 \\
(0.007)\end{array}$ \\
\hline Education & $\begin{array}{r}-0.090 * * * \\
(0.005)\end{array}$ & $\begin{array}{r}-0.047 * * * \\
(0.004)\end{array}$ & $\begin{array}{r}-0.047 * * * \\
(0.004)\end{array}$ \\
\hline Married & $\begin{array}{r}-0.015 \\
(0.021)\end{array}$ & $\begin{array}{r}-0.004 \\
(0.020)\end{array}$ & $\begin{array}{r}-0.005 \\
(0.020)\end{array}$ \\
\hline Female & $\begin{array}{r}-0.102 * * * \\
(0.021)\end{array}$ & $\begin{array}{r}-0.059 * * * \\
(0.014)\end{array}$ & $\begin{array}{r}-0.059 * * * \\
(0.014)\end{array}$ \\
\hline Life events (onset) & & & \\
\hline Bereaved & $\begin{array}{r}-0.006 \\
(0.032)\end{array}$ & $\begin{array}{r}0.012 \\
(0.029)\end{array}$ & $\begin{array}{r}0.014 \\
(0.029)\end{array}$ \\
\hline Death of a parent, sibling, (grand)child & $\begin{array}{c}0.032 * \\
(0.017)\end{array}$ & $\begin{array}{c}0.024^{*} \\
(0.014)\end{array}$ & $\begin{array}{l}0.023^{*} \\
(0.014)\end{array}$ \\
\hline Illness of partner or relatives & $\begin{array}{r}-0.121 * * * \\
(0.016)\end{array}$ & $\begin{array}{r}-0.088^{* * *} \\
(0.013)\end{array}$ & $\begin{array}{r}-0.087 * * * \\
(0.013)\end{array}$ \\
\hline Financial problems & $\begin{array}{r}-0.018 \\
(0.012)\end{array}$ & $\begin{array}{r}-0.006 \\
(0.011)\end{array}$ & $\begin{array}{r}-0.006 \\
(0.011)\end{array}$ \\
\hline CVA (stroke) & & & $\begin{array}{r}0.112 * * * \\
(0.040)\end{array}$ \\
\hline Heart disease & & & $\begin{array}{r}-0.007 \\
(0.025)\end{array}$ \\
\hline Respiratory diseases & & & $\begin{array}{r}-0.032 \\
(0.035)\end{array}$ \\
\hline Arteriosclerosis & & & $\begin{array}{c}-0.058^{*} \\
(0.034)\end{array}$ \\
\hline Diabetes & & & $\begin{array}{r}0.034 \\
(0.042)\end{array}$ \\
\hline Cancer & & & $\begin{array}{c}-0.036 \\
(0.029)\end{array}$ \\
\hline Number of chronic conditions & $\begin{array}{l}0.106^{*} \\
(0.059)\end{array}$ & $\begin{array}{r}0.054 \\
(0.046)\end{array}$ & $\begin{array}{r}0.060 \\
(0.046)\end{array}$ \\
\hline Conditions at birth & & & \\
\hline Trough years & $\begin{array}{r}-0.025 \\
(0.028)\end{array}$ & $\begin{array}{r}-0.012 \\
(0.018)\end{array}$ & $\begin{array}{r}-0.010 \\
(0.018)\end{array}$ \\
\hline Peak years & $\begin{array}{r}-0.062 * * \\
(0.025)\end{array}$ & $\begin{array}{r}-0.032 * * \\
(0.016)\end{array}$ & $\begin{array}{c}-0.030^{*} \\
(0.016)\end{array}$ \\
\hline Constant & $\begin{array}{r}0.906 * * * \\
(0.279)\end{array}$ & $\begin{array}{r}0.100 \\
(0.242)\end{array}$ & $\begin{array}{r}0.137 \\
(0.242)\end{array}$ \\
\hline $\begin{array}{l}\text { Observations } \\
\text { R-squared }\end{array}$ & $\begin{array}{r}6490 \\
0228\end{array}$ & $\begin{array}{r}6478 \\
0381\end{array}$ & $\begin{array}{r}6481 \\
0382\end{array}$ \\
\hline
\end{tabular}

Cognition is measured by $\log (31-$ MMSE). High values are associated with worse cognition

Robust clustered standard errors in parentheses. $* * * \mathrm{p}<0.01, * * \mathrm{p}<0.05, * \mathrm{p}<0.1$ 


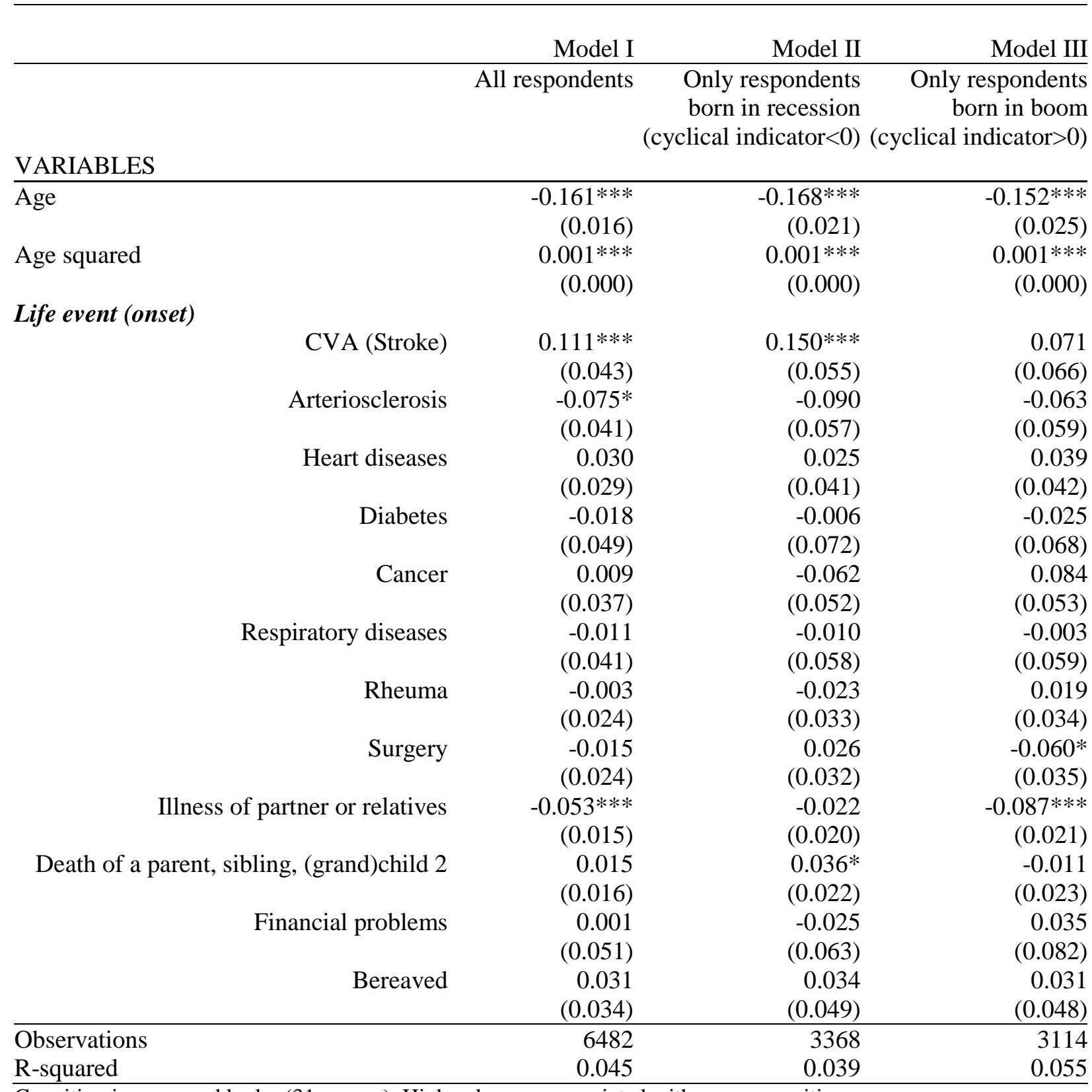

Cognition is measured by $\log (31-\mathrm{mmse})$. High values are associated with worse cognition $* * * \mathrm{p}<0.01, * * \mathrm{p}<0.05, * \mathrm{p}<0.1$ Robust clustered standard errors in parentheses 


\begin{tabular}{|c|c|c|c|c|}
\hline & \multicolumn{2}{|c|}{ MALES } & \multicolumn{2}{|c|}{ FEMALES } \\
\hline & $\begin{array}{l}\text { Only males born } \\
\text { in recession } \\
(\text { cyclical } \\
\text { indicator }<0) \\
\end{array}$ & $\begin{array}{l}\text { Only males } \\
\text { born in boom } \\
\text { (cyclical } \\
\text { indicator }>0)\end{array}$ & $\begin{array}{l}\text { Only females } \\
\text { born in recession } \\
(\text { cyclical } \\
\text { indicator }<0)\end{array}$ & $\begin{array}{l}\text { Only females } \\
\text { born in boom } \\
\quad(\text { cyclical } \\
\text { indicator }>0)\end{array}$ \\
\hline \multicolumn{5}{|l|}{ VARIABLES } \\
\hline$\overline{\text { Age }}$ & $-0.158 * * *$ & $-0.180 * * *$ & $-0.179 * * *$ & $-0.128 * * *$ \\
\hline Age squared & $0.001 * * *$ & $0.002 * * *$ & $0.001 * * *$ & $0.001^{* * *}$ \\
\hline \multicolumn{5}{|l|}{ Life event (onset) } \\
\hline CVA (Stroke) & $\begin{array}{r}0.092 \\
(0.075)\end{array}$ & $\begin{array}{r}0.134 \\
(0.086)\end{array}$ & $\begin{array}{r}0.211^{* * * *} \\
(0.081)\end{array}$ & $\begin{array}{r}-0.022 \\
(0.105)\end{array}$ \\
\hline Arteriosclerosis & $\begin{array}{r}-0.136 \\
(0.083)\end{array}$ & $\begin{array}{r}-0.126 \\
(0.095)\end{array}$ & $\begin{array}{r}-0.027 \\
(0.079)\end{array}$ & $\begin{array}{r}-0.013 \\
(0.076)\end{array}$ \\
\hline Heart diseases & $\begin{array}{r}0.039 \\
(0.059)\end{array}$ & $\begin{array}{r}0.029 \\
(0.058)\end{array}$ & $\begin{array}{r}0.010 \\
(0.059)\end{array}$ & $\begin{array}{r}0.039 \\
(0.062)\end{array}$ \\
\hline Diabetes & $\begin{array}{l}-0.093 \\
(0.102)\end{array}$ & $\begin{array}{r}-0.020 \\
(0.112)\end{array}$ & $\begin{array}{r}0.055 \\
(0.100)\end{array}$ & $\begin{array}{r}-0.016 \\
(0.084)\end{array}$ \\
\hline Cancer & $\begin{array}{l}-0.085 \\
(0.069)\end{array}$ & $\begin{array}{r}0.128 \\
(0.079)\end{array}$ & $\begin{array}{l}-0.041 \\
(0.078)\end{array}$ & $\begin{array}{r}0.036 \\
(0.072)\end{array}$ \\
\hline Respiratory diseases & $\begin{array}{c}-0.054 \\
(0.077)\end{array}$ & $\begin{array}{r}0.002 \\
(0.078)\end{array}$ & $\begin{array}{r}0.029 \\
(0.087)\end{array}$ & $\begin{array}{r}-0.002 \\
(0.093)\end{array}$ \\
\hline Rheuma & $\begin{array}{r}-0.047 \\
(0.050)\end{array}$ & $\begin{array}{r}0.016 \\
(0.059)\end{array}$ & $\begin{array}{r}-0.006 \\
(0.043)\end{array}$ & $\begin{array}{r}0.022 \\
(0.042)\end{array}$ \\
\hline Surgery & $\begin{array}{r}0.001 \\
(0.046)\end{array}$ & $\begin{array}{l}-0.080 \\
(0.052)\end{array}$ & $\begin{array}{r}0.054 \\
(0.046)\end{array}$ & $\begin{array}{r}-0.046 \\
(0.050)\end{array}$ \\
\hline Illness of partner or relatives & $\begin{array}{l}-0.027 \\
(0.031)\end{array}$ & $\begin{array}{r}-0.124 * * * \\
(0.031)\end{array}$ & $\begin{array}{r}-0.017 \\
(0.026)\end{array}$ & $\begin{array}{c}-0.056^{*} \\
(0.029)\end{array}$ \\
\hline Death of a parent, sibling, grand)child & $\begin{array}{l}-0.013 \\
(0.031)\end{array}$ & $\begin{array}{l}-0.023 \\
(0.036)\end{array}$ & $\begin{array}{r}0.081 * * * * \\
(0.031)\end{array}$ & $\begin{array}{r}-0.002 \\
(0.029)\end{array}$ \\
\hline Financial problems & $\begin{array}{r}0.078 \\
(0.086)\end{array}$ & $\begin{array}{r}-0.125 \\
(0.111)\end{array}$ & $\begin{array}{l}-0.110 \\
(0.087)\end{array}$ & $\begin{array}{r}0.170 \\
(0.116)\end{array}$ \\
\hline Bereaved & $\begin{array}{r}0.017 \\
(0.089)\end{array}$ & $\begin{array}{r}0.065 \\
(0.082)\end{array}$ & $\begin{array}{r}0.050 \\
(0.059)\end{array}$ & $\begin{array}{r}0.008 \\
(0.060)\end{array}$ \\
\hline Observations & 1520 & 1419 & 1848 & 1695 \\
\hline R-squared & 0.040 & 0.071 & 0.045 & 0.047 \\
\hline
\end{tabular}

Cognition is measured by $\log (31-\mathrm{MMSE})$. High values are associated with worse cognition $* * * \mathrm{p}<0.01, * * \mathrm{p}<0.05, * \mathrm{p}<0.1$. Robust clustered standard errors in parentheses 
Table 8 FIXED EFFECTS REGRESSED ON INDICATORS OF EARLY LIFE CONDITIONS AND OTHER TIME CONSTANT VARIABLES

MODEL I MODEL II

VARIABLES

Year of birth

Education

Female

Married

Education

Presence of chronic condition at wave I

Respiratory diseases

Heart diseases

Arteriosclerosis

CVA (Stroke)

Diabetes

Cancer

Rheuma

\section{Conditions at birth}

Cyclical component of business cycle

Trough years

Peak years

$\begin{array}{rr}-0.014 * * * & -0.014 * * * \\ (0.001) & (0.001) \\ -0.091 * * * & -0.091 * * * \\ (0.005) & (0.005) \\ -0.103 * * * & -0.104 * * * \\ (0.023) & (0.023) \\ -0.069 * * * & -0.070 * * * \\ (0.024) & (0.024) \\ -0.091 * * * & -0.091 * * *\end{array}$

$-0.024$

$-0.024$

$(0.034)$

0.027

$(0.028)$

0.041

$(0.039)$

$0.129 * *$

$(0.054)$

0.022

$(0.047)$

0.004

$(0.039)$

$-0.009$

$(0.019)$

(0.034)

0.027

(0.028)

0.042

(0.039)

0.127 **

(0.054)

0.024

(0.047)

0.008

(0.039)

$-0.009$

(0.019)

$-0.201$

(0.157)

$-0.007$

(0.029)

$-0.051 * *$

(0.026)

\begin{tabular}{lrr} 
Constant & $1.807 * * *$ & $1.816^{* * * *}$ \\
& $(0.042)$ & $(0.042)$ \\
\hline Observations & 2264 & 2264 \\
R-squared & 0.189 & 0.190 \\
\hline$* * * p<0.01, * * \mathrm{p}<0.05, * \mathrm{p}<0.1$ Robust standard errors in parentheses
\end{tabular}


Figure 1.1 MITIGATING ROLE OF EARLY-LIFE CONDITIONS ON THE EFFECT OF ADVERSE EVENTS LATER IN LIFE ON COGNITIVE ABILITY.

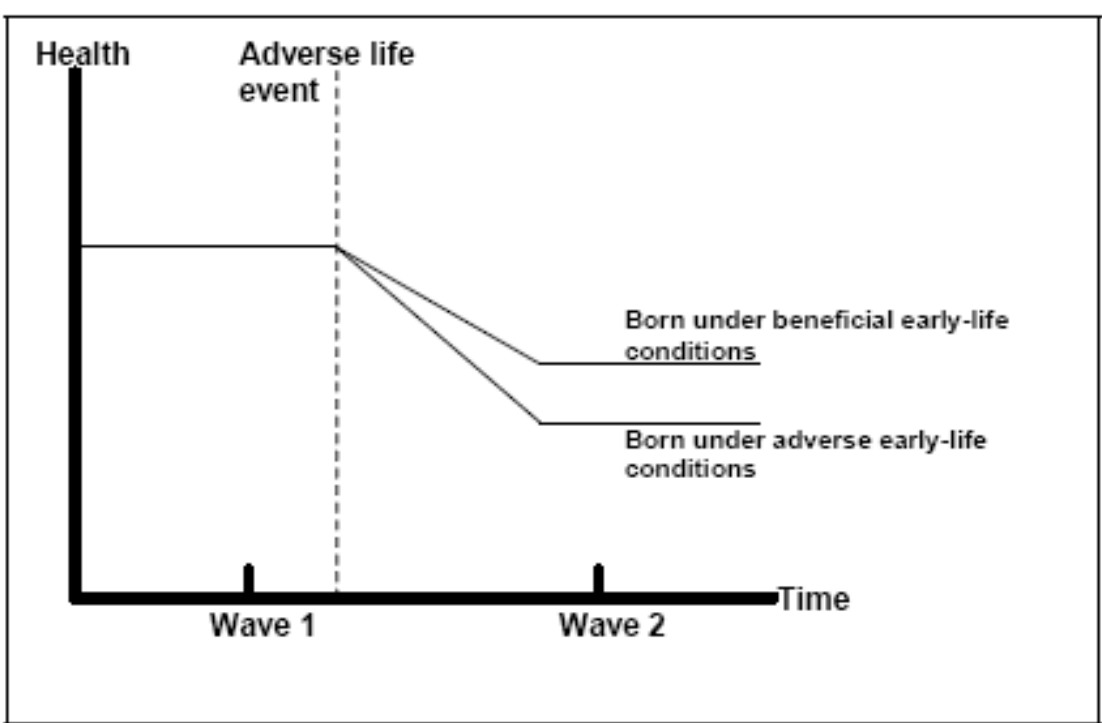


Figure 1.2 EARLY-LIFE CONDITIONS, ADVERSE LIFE EVENTS AND LATER-LIFE COGNITION

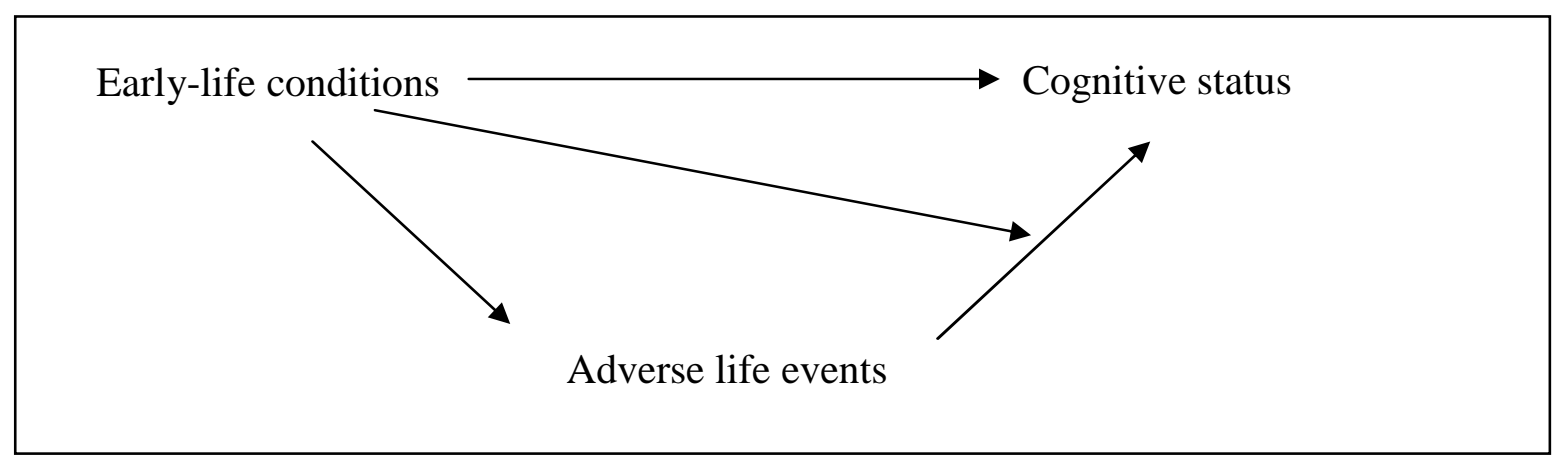


Figure 2.1 MMSE DISTRIBUTION AT WAVES I-V

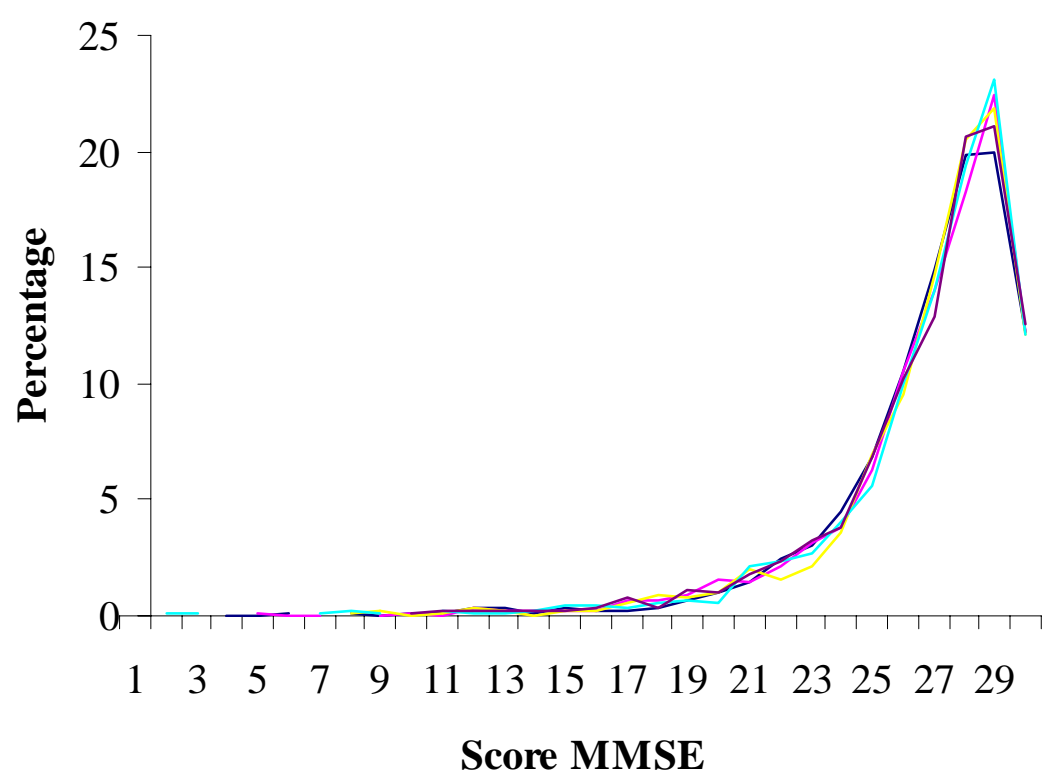

- Wave I — Wave II — Wave III Wave IV — Wave V 
Figure 2: Cyclical fluctuations Log(real per capita annual GDP)

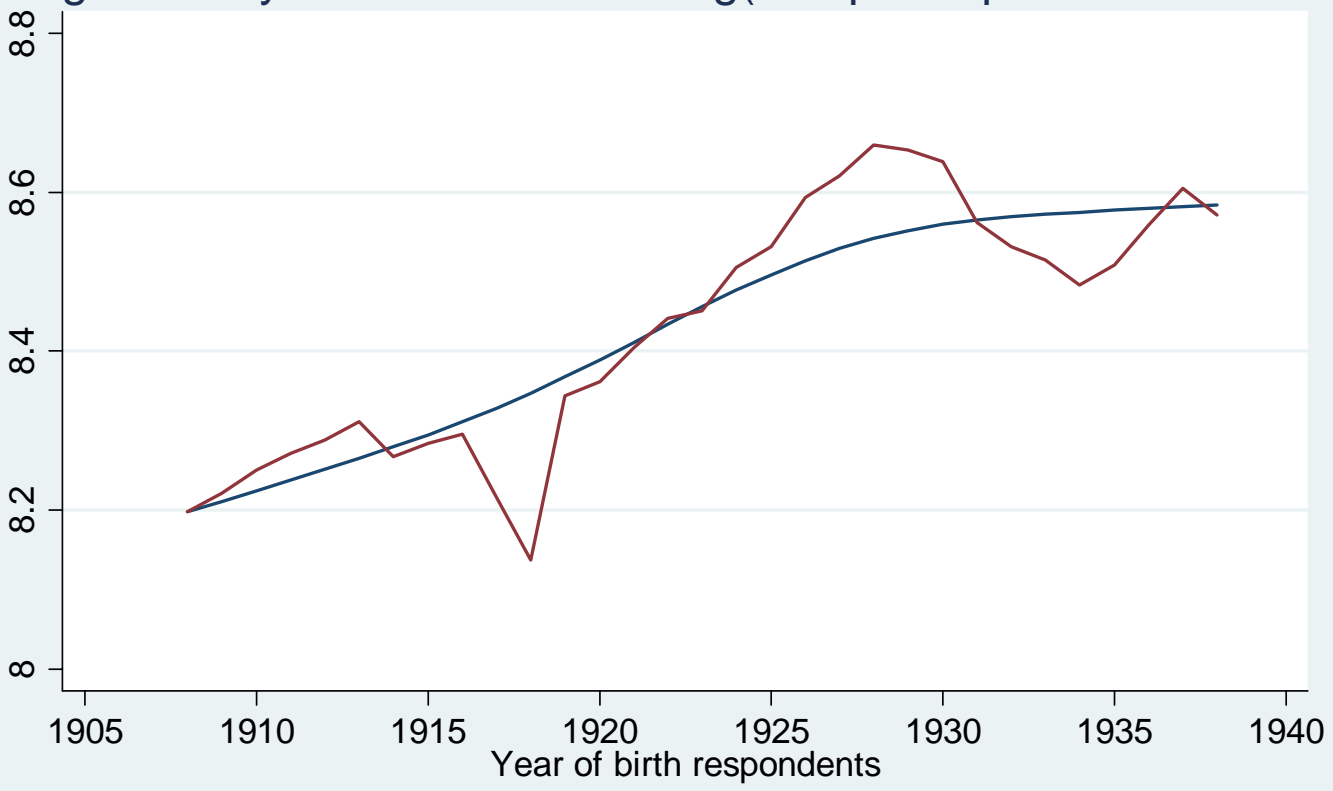

